\title{
Synthesis of Optically Pure Macroheterocycle with Ester and Hydrazide Fragments on the Basis of 1 -Menthol
}

\author{
Gumer Yu. Ishmuratov, Marina P. Yakovleva, ${ }^{@}$ Galina R. Mingaleeva, Mariya A. \\ Shutova, Rinat R. Muslukhov, Evgeny M. Viripaev, and Alexander G. Tolstikov
}

Institute of Organic Chemistry, Ufa Scientific Centre of RAS, 450054 Ufa, Russia

${ }^{\circledR}$ Corresponding author E-mail: insect@anrb.ru

\begin{abstract}
Based on l-menthol we have developed a synthesis method for potentially useful optically pure methyl-and isopropylbranched 21-member macrolide with hydrazide and ester fragments via sequential [2+1]-condensation of methyl(3R,6S)-6-hydroxy-3,7-dimethyl octanoate with glutaric acid chloranhydride and [1+1]-reaction of intermediate tetraester with hydrazine hydrate. The evidence is given for the structure of the obtained macrocycle using IR and NMR spectroscopy and mass spectrometry.
\end{abstract}

Keywords: $l$-Menthol, $O, N$-macroheterocycles, ester and hydrazide functions, synthesis.

\section{Синтез оптически чистых макрогетероциклов со сложноэфирными и гидразидными фрагментами на основе I-ментола}

\author{
Г. Ю. Ишмуратов, М. П. Яковлева, ${ }^{@}$ Г. Р. Мингалеева, М. А. Шутова, Р. Р. \\ Муслухов, Е. М. Вирипаев, А. Г. Толстиков
}

Институт органической химии Уфимского научного иентра Российской академии наук, 450054 Уфа, Российская Федераиия

${ }^{\circledR}$ E-mail: insect@anrb.ru

\begin{abstract}
Разработан метод синтеза оптически чистого метил- и изо-пропил-замещенного 21-членного макролида с гидразидными и сложноэфирными фрагментами. Структура полученного соединения была подтверждена с помощьью ИК и ЯМР спектроскопии и масс-спектрометрии.
\end{abstract}

Ключевые слова: $l$-Ментол, $O, N$-макрогетероциклы, сложноэфирные и гидразидные фрагменты, синтез.

\footnotetext{
Modern practical medicine successfully employs pharmaceutical preparations with oxygen and nitrogen containing macrocyclic compounds as drug substances. ${ }^{[1]}$ Therefore, the development of methods for obtaining macroheterocycles containing pharmacophoric fragments presents a crucial problem for further modern pharmacology and chemical science.

This report describes a synthetic route to potentially bioactive optically pure methyl and isopropyl branched 21member macrolide with hydrazide and ester groups fabricated from accessible natural $l$-menthol.
}

\section{Experimental}

IR spectra in thin layers were recorded on IR Prestige-21 Shimadzu instrument. NMR spectra were recorded in $\mathrm{CDCl}_{3}$ with TMS internal standard and in $\mathrm{MeOH}+\mathrm{C}_{6} \mathrm{D}_{6}$ with DSS internal standard on a Bruker AM-300 spectrometer (operating frequency $300.13 \mathrm{MHz}$ for ${ }^{1} \mathrm{H} ; 75.47,{ }^{13} \mathrm{C}$ ). ${ }^{13} \mathrm{C}$ NMR spectra were written down in modes with a broadband outcome on protons and in the JMOD mode. Chromatography was carried out in Chrom-5 [column length $1.2 \mathrm{~m}$, stationary phase SE-30 (5\%) silicone on Chromaton N-AWDMCS $\left.(0.16-0.20 \mathrm{~mm}), 50-300^{\circ} \mathrm{C}\right]$ instrument with $\mathrm{He}$ carrier gas. Column chromatography used $\mathrm{SiO}_{2}$ (70-230, Lancaster, England). 
TLC monitoring used Sorbfil $\mathrm{SiO}_{2}$ (Russia). Elemental analyses of all compounds were agreed with those calculated. Mass spectra of compounds 3, 5 were recorded on Shimadzu LCMS 2010 EV instrument using under atmospheric pressure chemical ionization (APCI) with electron energy $20 \mathrm{eV}$ and detection of positive and negative ions. The liquid mobile phase was $\mathrm{H}_{2} \mathrm{O}$ and/or $\mathrm{CH}_{3} \mathrm{CN}$ at flow rate $0.02 \mathrm{ml} / \mathrm{min}$

Methyl-(3R,6S)-6-hydroxy-3,7-dimethyloctanoate, $\quad 2 . \quad$ To the stirred solution of mentholactone $\mathbf{1}^{[2]}(10.0 \mathrm{~g}, 58.8 \mathrm{mmol})$ in $100 \mathrm{ml}$ abs. methanol three drops of conc. $\mathrm{H}_{2} \mathrm{SO}_{4}$ were added and left to stand for $24 \mathrm{hrs}$ (with TLC control). Thereafter, methanol was sublimed; the residue was diluted with ethyl acetate (100 ml) and sequentially rinsed with saturated $\mathrm{NaCl}, \mathrm{NaHCO}_{3}$ and $\mathrm{NaCl}$ solutions; the organic layer was dessicated with $\mathrm{MgSO}_{4}$ and sublimed. Yield: $10.3 \mathrm{~g}(87 \%)$ by ester 3, the IR and NMR spectral parameters were similar to those obtained previously. ${ }^{[2]}$

1,2-Bis ((3R,6S)-6-hydroxy-3,7-dimethyl-1-oxooctyl)hydrazine, 3. To $3.00 \mathrm{~g}$ (14.9 mmol) of methyl-(3R,6S)-6-hydroxy3,7-dimethyloctanoate (2) in $5 \mathrm{ml}$ of dioxane $0.37 \mathrm{~g}$ (7.4 mmol) hydrazine monohydrate was slowly dropwise added, stirred for 4 hrs (until disappearance of $\mathbf{2}$, with TLC control); dioxane was sublimed, and the residue was filtered through Schott filter, under rinsing with $20 \mathrm{ml}$ MTBE. Yield $2.48 \mathrm{~g}(90 \%)$. $[\alpha]_{\mathrm{D}}{ }^{20}-5.7^{\circ}(c 1.27$, $\left.\mathrm{CH}_{3} \mathrm{OH}\right) . m / z$ (APCI, $20 \mathrm{eV}$ ): $373\left[(\mathrm{M}+\mathrm{H})^{+}\right], 371\left[(\mathrm{M}-\mathrm{H})^{-}\right] .{ }^{1} \mathrm{H}$ NMR $\left(\mathrm{MeOH}+\mathrm{C}_{6} \mathrm{D}_{6}\right) \delta \mathrm{ppm}: 0.80\left(6 \mathrm{H}, \mathrm{d}, J=6.7 \mathrm{~Hz}, \mathrm{CH}_{3}-3\right), 1.08(12 \mathrm{H}$, $\left.\mathrm{d}, J=6.7 \mathrm{~Hz}, \mathrm{CH}_{3}-7\right), 1.17-1.24(4 \mathrm{H}, \mathrm{m}, \mathrm{H}-4), 1.30-1.45(2 \mathrm{H}, \mathrm{m}$, H'-5), 1.40-1.62 (2H, m, H'-5), 1.78 (2H, q, $J=6.8 \mathrm{~Hz}, \mathrm{H}-7), 1.81-$ $1.87(2 \mathrm{H}, \mathrm{m}, \mathrm{H}-3), 2.06(4 \mathrm{H}, \mathrm{d}, J=7.1 \mathrm{~Hz}, \mathrm{H}-2), 3.51-3.82(2 \mathrm{H}, \mathrm{m}$, $\mathrm{H}-6), 6.02(1 \mathrm{H}, \mathrm{s}, \mathrm{OH}), 9.18(2 \mathrm{H}, \mathrm{s}, \mathrm{NH}) .{ }^{13} \mathrm{C} \mathrm{NMR}\left(\mathrm{MeOH}+\mathrm{C}_{6} \mathrm{D}_{6}\right)$ $\delta$ ppm: 17.09, 18.81 (q, $\left.\mathrm{CH}_{3} \mathrm{C}-8\right), 19.46\left(\mathrm{q}, \mathrm{CH}_{3} \mathrm{C}-3\right), 31.24(\mathrm{~d}$, C-3), 31.66 (t, C-5), 33.53 (t, C-4), 33.99 (d, C-7), 41.73 (t, C-2), $76.82(\mathrm{~d}, \mathrm{C}-6), 173.66(\mathrm{~s}, \mathrm{C}-1) . \mathrm{IR}(\mathrm{KBr}) v_{\max } \mathrm{cm}^{-1}: 3285-3170(\mathrm{NH}$, $\mathrm{OH}), 1651,1629$ (CONH).

Bis [(1'S, 4'R)-1'-isopropyl-6'-methoxy-4'-methyl-6'oxohexyl]pentane dioate, 4 . To the stirred solution of methyl(3R,6S)-6-hydroxy-3,7-dimethyl octanoate (2) $(3.00 \mathrm{~g}, 14.9 \mathrm{mmol})$ in $8 \mathrm{ml}$ abs. pyridine glutaric acid chloranhydride $(3.10 \mathrm{~g}, 7.4 \mathrm{mmol})$ ${ }^{[3]}$ in $3 \mathrm{ml}$ abs. ether was added, stirred for $24 \mathrm{hrs}$ (until disappearance of 2 , TLC control). The reaction mixture was diluted with $50 \mathrm{ml}$ of diethyl ester, sequentially rinsed with $5-\mathrm{pc} \mathrm{HCl}$, saturated by $\mathrm{NaCl}$ solution and dessicated with $\mathrm{MgSO}_{4}$; the solvent was sublimed, and the residue was chromatographed. Yield $2.10 \mathrm{~g}(57 \%) . R_{\mathrm{f}} 0.18$ $\left(\mathrm{SiO}_{2}\right.$, petroleum ether - MTBE, 2:1). $[\alpha]_{\mathrm{D}}^{20}+1.4^{\circ}\left(\mathrm{c} 1.88, \mathrm{CH}_{2} \mathrm{Cl}_{2}\right)$. ${ }^{1} \mathrm{H}$ NMR $\left(\mathrm{CDCl}_{3}\right) \delta \mathrm{ppm}: 0.85\left(12 \mathrm{H}, \mathrm{d}, J=6.8 \mathrm{~Hz}, \mathrm{CH}_{3}-i-\mathrm{Pr}\right), 0.92$ $\left(6 \mathrm{H}, \mathrm{d}, J=6.7 \mathrm{~Hz}, \mathrm{CH}_{3}-4^{\prime}\right), 1.12-1.35\left(2 \mathrm{H}, \mathrm{m}, \mathrm{H}^{\prime}-3{ }^{\prime}\right), 1.45-1.60$ (2H, m, H"-3'), 1.49-1.58 (4H, m, H-3, H-4'), 1.78-1.89 (2H, m, CH-i-Pr), 1.88-2.21 (4H, m, H-2'), 2.11 (2H, dd, $J=14.4,8.1 \mathrm{~Hz}$, H'-5'), 2.29 ( $2 \mathrm{H}, \mathrm{dd}, J=14.4,5.9 \mathrm{~Hz}, \mathrm{H}^{\prime}-5$ '), 2.38 (4H, t, $J=7.3$ $\mathrm{Hz}, \mathrm{H}-2, \mathrm{H}-4), 3.64\left(6 \mathrm{H}, \mathrm{s}, \mathrm{CH}_{3}-\mathrm{O}\right), 4.72(2 \mathrm{H}, \mathrm{dt}, J=8.1,4.2 \mathrm{~Hz}$, $\left.\mathrm{H}-1^{\prime}\right) .{ }^{13} \mathrm{C}$ NMR $\left(\mathrm{CDCl}_{3}\right) \delta$ ppm: 17.26, $18.48\left(\mathrm{q}, \mathrm{CH}_{3}-i-\mathrm{Pr}\right), 19.60$ (q, $\mathrm{CH}_{3}-\mathrm{C}-4$ '), 20.35 (t, C-3), 28.30 (t, C-2'), 30.17 (d, C-4'), 30.98 (d, CH-i-Pr), 32.23 (t, C-3'), 33.50 (t, C-2, C-4), 41.21 (t, C-5'), 51.26 (q, $\mathrm{CH}_{3}-\mathrm{O}$ ), 78.33 (d, C-1'), 172.67 (s, C-1, C-5), 173.36 (s, C-6'). IR ( $\mathrm{KBr}) v_{\max } \mathrm{cm}^{-1}: 1732(\mathrm{O}=\mathrm{C}-\mathrm{O})$.

(8S,11R,18R,21S)-8,21-Diisopropyl-11,18-dimethyl-1,7dioxa-14,15-diazacyclogeneicosane-2,6,13,16-tetron, 5 . To the solution of tetraester $4(1.35 \mathrm{~g}, 2.7 \mathrm{mmol})$ in $10 \mathrm{ml}$ abs. dioxane hydrazine hydrate $(0.14 \mathrm{~g}, 2.7 \mathrm{mmol})$ was slowly added dropwise under intense stirring and it was stirred for $6 \mathrm{hrs}$ (until disappearance of 4, with TLC control); dioxane was sublimed. The residue was diluted in $20 \mathrm{ml} \mathrm{CH} \mathrm{Cl}_{2}$, rinsed with water $(3 \times 5 \mathrm{ml})$, dessicated with $\mathrm{MgSO}_{4}$ and sublimed. To the resulting residue we sequentially

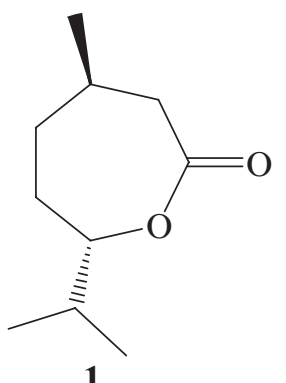

1<smiles>COC(=O)C[C@@H](C)[C@H](CC(O)C(C)C)OC</smiles>

2<smiles>CCCCC(C)=O</smiles><smiles>CC(=O)CC(C)C</smiles>

$\mathrm{N}_{2} \mathrm{H}_{4} \cdot \mathrm{H}_{2} \mathrm{O}$ $50 \%$<smiles></smiles><smiles>CC(C)C[C@@H](C)CC(=O)NNC(=O)C[C@H](C)CC[C@H](OC(=O)C(C)C)C(C)C</smiles>

5

Scheme 1. 
added $1 \mathrm{ml}$ of dry $\mathrm{CH}_{2} \mathrm{Cl}_{2}$ and $10 \mathrm{ml}$ hexane under stirring and left to stand until the layers separated, the upper one being decanted. The residue was rinsed with $5 \mathrm{ml}$ hexane and sublimed. The yield was $0.46 \mathrm{~g}(50 \%)$ of the compound 5. $[\alpha]_{\mathrm{D}}{ }^{20}+0.6^{\circ}\left(\mathrm{c} 2.23, \mathrm{CH}_{2} \mathrm{Cl}_{2}\right) . \mathrm{m} / \mathrm{z}$ (APCI, $20 \mathrm{eV}): 487\left[\left(\mathrm{M}+\mathrm{H}+\mathrm{H}_{2} \mathrm{O}\right)^{+}\right], 485\left[\left(\mathrm{M}-\mathrm{H}+\mathrm{H}_{2} \mathrm{O}\right)^{-}\right] .{ }^{1} \mathrm{H}$ NMR $\left(\mathrm{CDCl}_{3}\right) \delta$ ppm: $0.89\left(12 \mathrm{H}, \mathrm{d}, J=6.8 \mathrm{~Hz}, \mathrm{CH}_{3}-i-\mathrm{Pr}\right), 0.91(6 \mathrm{H}, \mathrm{d}, J=$ $\left.6.7 \mathrm{~Hz}, \mathrm{CH}_{3}-11, \mathrm{CH}_{3}-18\right), 1.01-1.25$ (2H, m, H-11, H-18), 1.38-1.55 (4H, m, H-10, H-19), 1.41-1.56 (2H, m, H-4), 1.75-1.98 (4H, m, H-9, H-20), 1.78-1.92 (2H, m, CH- $i$-Pr), 2.05 (2H, dd, $J=14.0,5.7$ Hz, H'-12, H'-17), 2.23 (2H, dd, $J=14.0,7.9$ Hz, H'-12, H'-17), 2.32 (4H, t, $J=7.1 \mathrm{~Hz}, \mathrm{H}-3, \mathrm{H}-5), 4.67$ (2H, dt, $J=8.0,4.7 \mathrm{~Hz}, \mathrm{H}-8$, $\mathrm{H}-21), 8.06(2 \mathrm{H}, \mathrm{s}, \mathrm{NH}) .{ }^{13} \mathrm{C} \mathrm{NMR}\left(\mathrm{CDCl}_{3}\right) \delta \mathrm{ppm}: 17.12,18.34(\mathrm{q}$, $\mathrm{CH}_{3}-i-\mathrm{Pr}$ ), 19.47 (q, $\left.\mathrm{CH}_{3}-\mathrm{C}-11, \mathrm{CH}_{3}-\mathrm{C}-18\right), 20.21$ (t, C-4), 28.30 (t, C-9, C-20), 30.00 (d, C-11, C-18), 30.84 (d, CH-i-Pr), 32.08 (t, C-10, C-19), 33.30 (t, C-3, C-5), 41.56 (t, C-12, C-17), 78.13 (d, C-8, C-21), 172.43 (s, C-2, C-6), 173.07 (s, C-13, C-16). IR (KBr) $v_{\max } \mathrm{cm}^{-1}: 3292(\mathrm{NH}), 1735(\mathrm{O}=\mathrm{C}-\mathrm{O}), 1635,1701(\mathrm{CONH})$.

\section{Results and Discussion}

The synthesis scheme (Scheme 1) is based on chemoand regioselective transformations of mentholactone 1 obtained from natural $l$-menthol in two stages. ${ }^{[2]} \mathrm{Re}$ esterification of cyclic ether $\mathbf{1}$ with methanol in presence of $\mathrm{H}_{2} \mathrm{SO}_{4}$ gave methyl-(3R,6S)-6-hydroxy-3,7-dimethyl octanoate (2), [2+1]-condensation of which with absolute glutaric acid chloranhydride resulted in bis $[(1 S, 4 R)-1$-isopropyl-6-methoxy-4-methyl-6-oxyhexyl]pentane dioate (4).

Involvement of the latter into the $[1+1]$-condensation reaction with hydrazine hydrate made it possible to get the target macroheterocycle $\mathbf{5}$ containing hydrazide and ester groups.

An alternative attempt to synthesize the macrocycle $\mathbf{5}$ via [2+1]-condensation of methyl-(3R,6S)-6-hydroxy-3,7dimethyl octanoate (2) with hydrazine hydrate followed by $[1+1]$-condensation of the resulting 1,2-bis $((3 R, 6 S)$ 6-hydroxy-3,7-dimethyl-1-oxooctyl)hydrazine (3) with glutaric acid chloranhydride failed at the second stage, even with another solvent $\left(\mathrm{CCl}_{4}\right.$ was changed for 1,4-dioxane) plus the $\mathrm{CoCl}_{2}$ catalyst previously used in ${ }^{[4]}$.

The structures of the resulting acyclic compounds $\mathbf{3 , 4}$ and macrolide 5 were established by $\mathrm{IR},{ }^{1} \mathrm{H}$ and ${ }^{13} \mathrm{C}$ NMR spectroscopic techniques; the molecular mass was measured using chromatic mass spectrometry.

The IR spectra of the acyclic compound $\mathbf{3}$ and macrolide 5 do not have an absorption band in the region of $1735 \mathrm{~cm}^{-1}$ characteristic of the carboxylic function of the compound 2. The presence of signals corresponding to the $\mathrm{CONH}$ fragment (1627 and $1651 \mathrm{~cm}^{-1}$ for 3; 1635 and $1701 \mathrm{~cm}^{-1}$ for 5) and $\mathrm{N}-\mathrm{H}$ bond $\left(3284 \mathrm{~cm}^{-1}\right.$ for 3 and $3292 \mathrm{~cm}^{-1}$ for $\left.\mathbf{5}\right)$ evidences for the formation of a hydrazide group. The IR spectrum of the acyclic compound $\mathbf{4}$ does not have the absorption bands at 3300-3600 and $1099 \mathrm{~cm}^{-1}$ for the hydroxyl group, and the presence of the absorption bands at 1732 and $1728 \mathrm{~cm}^{-1}$ indicates the formation of tetraester 4 .
NMR data analysis of the compound $\mathbf{5}$ was performed through comparison of those known for acyclic tetraester 4 . The carbon signal of the COOMe grouping in the ${ }^{13} \mathrm{C} N M R$ spectrum of the product $5(173.36 \mathrm{ppm})$, obtained from the initial 4, and proton signals of the hydrazide $\left(\mathrm{NH}_{2} \mathrm{NHCO}\right)$ residue $(\sim 4.90 \mathrm{ppm})$ in the ${ }^{1} \mathrm{H}$ NMR spectrum are absent. This indicates that the compound $\mathbf{5}$ is not an acyclic product.

Besides a carbon signal of the ester groups (172.43 ppm), we can observe a singlet of $\mathrm{NHC}=\mathrm{O}$ groups $(173.07 \mathrm{ppm})$ in the ${ }^{13} \mathrm{C}$ NMR spectrum of the compound 5. Proton spectrum displays a downfield signal (8.06 ppm), the chemical shift value and integral intensity of which correspond to the two protons of $\mathrm{NHC}=\mathrm{O}$ groups. This is testimony to the formation of a hydrazide $[-\mathrm{C}(\mathrm{O}) \mathrm{NHNHC}(\mathrm{O})$-] fragment. All these spectral data point out to the formation of the macrocycle 5 with ester and hydrazide functions, that being additionally supported by mass spectrometry data.

Acyclic tetraester $\mathbf{3}$ and macroheterocycle $\mathbf{5}$ were investigated under atmospheric pressure chemical ionization (APCI) with recording positive and negative ions $(20 \mathrm{eV})$. In this case we noted very intense peaks of protonated $\mathrm{MH}^{+}$ and deprotonated (M-H)- ions as well as their ionic associates with water molecules, since protonation and water solvatization capabilities are well-known facts in the chemistry of amides and hydrazides. ${ }^{[5]}$

\section{Conclusions}

On the basis of $l$-menthol we have developed a synthetic method for the optically active macrocycle $\mathbf{5}$ with two ester and hydrazide functions using [2+1]-condensation of methyl(3R,6S)-6-hydroxy-3,7-dimethyloctanoate with glutaric acid chloranhydride and [1+1]-reaction of intermediate tetraester with hydrazine hydrate at key stages. The structure of the macrolide 5 was established by IR, ${ }^{1} \mathrm{H}$ and ${ }^{13} \mathrm{C}$ NMR spectroscopic techniques and chromatic mass spectrometry.

\section{References}

1. Ovchinnikov Yu.A. Bioorganicheskaya Khimiya [Bioorganic Chemistry]. Moskva: Prosveshcheniye, 1987. 816 p.

2. Ishmuratov G.Yu., Yakovleva M.P., Ganieva V.A., Muslukhov R.R., Tolstikov G.A. Chem. Nat. Compd. 2005, 41, 41-44 [Khimiya Prirodnykh Soedinenii 2005, 33-36 (in Russ.)].

3. Weygand-Hilgetag.Organisch-ChemischeExperimentierkunst. Leipzig: Verlag, 1968. 944 p.

4. Kataev V.E., Militsina O.I., Strobykina I.Yu., Kovylyaeva G.I., Musin R.Z., Fedorova O.V., Rusinov G.L., Zueva M.N., Mordovskoi G.G., Tolstikov A.G. Pharm. Chem. J. 2006, 40, 473-475 [Khimiko-Farmatsevticheskii Zh. 2006, 40, 12-13 (in Russ.)].

5. Obshchaya Organicheskaya Khimiya. Moskva: Khimiya, 1983, Vol 4. 438 p. (Russ. transl. of Comprehensive Organic Chemistry: The Synthesis and Reactions of Organic Compounds [Barton D., Ollis W.D., Eds.]. Vol. 4: Heterocyclic Compounds. Oxford: Pergamon Press, 1979). 